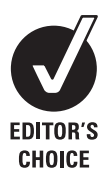

CHOICE

\title{
Lymphogranuloma venereum presenting as genital ulceration and inguinal syndrome in men who have sex with men in London, UK
}

\author{
G Sethi, ${ }^{1}$ E Allason-Jones, ${ }^{2} \mathrm{~J}$ Richens, ${ }^{3} \mathrm{~N}$ T Annan, ${ }^{4} \mathrm{D}$ Hawkins, ${ }^{4}$ A Ekbote, ${ }^{1}$ \\ S Alexander, ${ }^{5} \mathrm{~J}$ White ${ }^{1}$
}

\section{See Editorial, p 157}

${ }^{1}$ Department of Genitourinary Medicine, Guy's and St Thomas' NHS Foundation Trust, London, UK; ${ }^{2}$ The Mortimer Market Centre, Camden Primary Care Trust, London, UK; ${ }^{3}$ Centre for Sexual Health and HIV Research, University College London, London, UK; ${ }^{4}$ St Stephen's Centre, Chelsea and Westminster Hospital NHS Foundation Trust, London, UK:

${ }^{5}$ Sexually Transmitted Bacteria Reference Laboratory, Health Protection Agency, Colindale, UK

Correspondence to: Dr John White, Department of Genitourinary Medicine, Guy's and St Thomas' NHS Foundation Trust, Lambeth Palace Road, London, SE1 7EH, UK

Accepted 20 November 2008 Published Online First 9 December 2008

\section{ABSTRACT}

Objectives: To describe a series of lymphogranuloma venereum (LGV) cases presenting as inguinal syndrome and/or genital ulceration seen among men who have sex with men (MSM) in London, UK.

Methods: Collaborative retrospective case note review. Clinicians from three London genitourinary medicine (GUM) clinics accessed by large populations of MSM within the current LGV outbreak collected clinical data from confirmed cases of LGV inguinal syndrome or genital ulcer. LGV was confirmed by the detection of LGV-specific DNA from specimens such as bubo aspirates, ulcer swabs, urethral swabs, first void urine and rectal biopsy material.

Results: There were 13 cases detected overall: 5 cases of urethral LGV infection with inguinal adenopathy, 3 cases of genital ulcer with LGV inguinal adenopathy, 3 cases of isolated LGV-associated inguinal buboes, 1 case of a solitary LGV penile ulcer and 1 case with a penile ulcer and bubonulus. Only 6 of the 13 were HIV positive and all tested negative for hepatitis $C$. The majority of cases reported few sexual contacts in the 3 months preceding their diagnosis.

Conclusions: Clinical manifestations of LGV in MSM have not been confined to proctitis in the current outbreak in the UK and a small but significant number of inguinogenital cases of LGV have been observed. Epidemiologically, many of the cases described seem to have occurred at the periphery of the current MSM LGV epidemic. Clinicians need to be vigilant for these less common presentations of LGV among MSM and specific diagnostic tests should be done from the relevant lesions.

Lymphogranuloma venereum (LGV) is caused by Chlamydia trachomatis serovars L1-L3. ${ }^{1}$ These serovars display tropism for the lymphatic system in contrast to serovars $\mathrm{A}-\mathrm{K}$ that affect mucocutaneous tissue. ${ }^{1}$ Endemic in Africa, the Caribbean and parts of Asia, ${ }^{1}$ the classical presentation of LGV is inguinal lymphadenitis and abscess formation sometimes preceded by anogenital ulceration. Since 2004 there has been a resurgence of LGV proctitis affecting predominantly men who have sex with men (MSM) who are HIV positive in the UK, Western Europe and the USA. ${ }^{2-4}$ Detected cases have had high rates of co-infection with other sexually transmitted infections (STIs), including hepatitis C. ${ }^{2}$ Anogenital ulceration and/or lymphadenitis has been reported rarely in the current MSM LGV epidemic. ${ }^{25}$

We describe 13 recent cases of LGV that presented with "classical" inguinogenital manifestations. LGV was detected, usually in the absence of other STIs and symptoms resolved after treatment with longcourse regimens of doxycycline or azithromycin.

\section{METHODS}

Clinicians from three inner London genitourinary medicine (GUM) clinics servicing large populations of MSM collected clinical data from confirmed cases of LGV inguinal syndrome or genital ulcer. Case histories were anonymised and relevant data were collated and compared. Written informed consent was obtained from all cases that provided clinical images for this paper. As this was a retrospective anonymised case note review, ethics committee approval was not sought from the participating centres.

Initial tests for $C$ trachomatis and other STIs were performed at the respective hospital laboratories using commercially available assays performed according to the instructions of the manufacturer. All 13 cases described had specimens confirmed as LGV using molecular tests performed at the Sexually Transmitted Bacteria Reference Laboratory (STBRL), Health Protection Agency, Colindale, UK. DNA was extracted from clinical specimens (ulcer swabs, urethral swabs, first void urine) using the MagNA Pure total NA kit (Roche Diagnostics GmbH, Mannheim, Germany) according to the manufacturer's instructions. In instances where limited clinical specimen was available (bubo aspirates and rectal biopsies), manual DNA extractions were performed using the OIAamp Viral Mini Kit (Oiagen, Crawley, UK). The chlamydia status of all referred specimens was confirmed initially using a plasmid-based real-time PCR method. ${ }^{6}$ The presence of LGV DNA was then detected using a LGV-specific pmpH real-time PCR assay.

\section{RESULTS}

\section{Clinical records}

The characteristics of the 13 cases are summarised in table 1.

All were MSM with a median age of 36 years (range 21-61). Ten were of white ethnicity, only six were infected with HIV and none tested positive for hepatitis $\mathrm{C}$ antibodies. Twelve cases presented with unilateral or bilateral inguinal adenopathy, four of whom had concurrent genital ulceration, and one patient presented with penile ulceration only. Five of the twelve men with inguinal adenopathy appear to have had urethral 
Table 1 Characteristics of 13 confirmed cases of lymphogranuloma venereum (LGV) presenting with inguinal syndrome and/or genital ulceration

\begin{tabular}{|c|c|c|c|c|c|c|c|c|c|}
\hline $\begin{array}{l}\text { Case number, } \\
\text { date \& clinic }\end{array}$ & $\begin{array}{l}\text { Ethnicity \& age } \\
\text { (years) }\end{array}$ & $\begin{array}{l}\text { Clinical } \\
\text { presentation }\end{array}$ & $\begin{array}{l}\text { Urethritis } \\
\text { symptoms }\end{array}$ & $\begin{array}{l}\text { HIV IgG } \\
\text { status }\end{array}$ & $\begin{array}{l}\text { Number of } \\
\text { sexual } \\
\text { contacts } \\
\text { in last } 3 \\
\text { months }\end{array}$ & $\begin{array}{l}\text { Negative STI } \\
\text { tests performed }\end{array}$ & $\begin{array}{l}\text { LGV-specific } \\
\text { PCR result }\end{array}$ & LGV serology & Treatment \\
\hline $\begin{array}{l}1^{*} \text { Dec } 2003 \\
\text { STH }\end{array}$ & White British 54 & $\begin{array}{l}\text { Tender unilateral } \\
4 \mathrm{~cm} \text { by } 5 \mathrm{~cm} \\
\text { inguinal } \\
\text { lymphadenopathy, } \\
\text { subsequent ruptured } \\
\text { bubo }\end{array}$ & Nil & $\begin{array}{l}\text { Positive CD4 } \\
615 \mathrm{VL}<50\end{array}$ & $>5$ & $\begin{array}{l}\text { Urethral, rectal } \\
\text { and pharyngeal } \\
\text { GC culture } \\
\text { FVU CT SDA } \\
\text { RPR (past history } \\
\text { of treated } \\
\text { syphilis) }\end{array}$ & $\begin{array}{l}\text { Positive (rectal } \\
\text { biopsy specimen } \\
\text { from subsequent } \\
\text { LGV proctitis) }\end{array}$ & $\begin{array}{l}\text { CGAb CFT negative } \\
\text { (titre }<20 \text { in Feb } \\
\text { 2005) }\end{array}$ & $\begin{array}{l}\text { Doxycycline } \\
100 \mathrm{mg} \text { twice } \\
\text { daily for } 3 \\
\text { weeks }\end{array}$ \\
\hline $\begin{array}{l}2 \text { Sept } 2005 \\
\text { C\&W }\end{array}$ & White British 56 & $\begin{array}{l}0.5 \mathrm{~cm} \text { scrotal and } \\
\text { perianal ulcers with } \\
\text { subsequent unilateral } \\
\text { inguinal } \\
\text { lymphadenopathy } \\
\text { and } 4 \mathrm{~cm} \text { by } 3 \mathrm{~cm} \\
\text { bubo formation }\end{array}$ & Nil & $\begin{array}{l}\text { Positive CD4 } \\
523 \mathrm{VL}<50\end{array}$ & 1 & $\begin{array}{l}\text { Urethral swab } \\
\text { and rectal swab } \\
\text { GC/CT (SDA) } \\
\text { Urethral, rectal } \\
\text { and pharyngeal } \\
\text { GC culture } \\
\text { Syphilis EIA, } \\
\text { TPPA, VDRL } \times 2 \\
\text { HSV culture } \times 2\end{array}$ & $\begin{array}{l}\text { Positive (scrotal } \\
\text { ulcer swab and } \\
\text { swab of fluid } \\
\text { from ruptured } \\
\text { bubo) }\end{array}$ & $\begin{array}{l}\text { Psittacosis/LGV } \\
\text { CFT negative (titres } \\
\text { 1:20 twice, } 2 \\
\text { weeks apart) }\end{array}$ & $\begin{array}{l}\text { Doxycycline } \\
100 \mathrm{mg} \text { twice } \\
\text { daily for } 17 \\
\text { days then } \\
\text { azithromycin } \\
1 \mathrm{~g} \text { daily for } 12 \\
\text { days then } \\
\text { azithromycin } \\
500 \text { mg daily } \\
\text { for } 5 \text { days }\end{array}$ \\
\hline $\begin{array}{l}4 \text { April } 2006 \\
\text { STH }\end{array}$ & White British 61 & $\begin{array}{l}0.7 \mathrm{~cm} \text { painless } \\
\text { solitary penile ulcer. } \\
\text { No } \\
\text { lymphadenopathy }\end{array}$ & Nil & Negative & 1 & $\begin{array}{l}\text { FVU and rectal } \\
\text { swab GC/CT } \\
\text { (SDA) } \\
\text { Rectal and } \\
\text { pharyngeal GC } \\
\text { culture } \\
\text { Syphilis IgM and } \\
\text { RPR (past history } \\
\text { of treated } \\
\text { syphilis) } \\
\text { HSV and } \\
\text { Treponema } \\
\text { pallidum PCR (in- } \\
\text { house assay) } \\
\text { from ulcer swab }\end{array}$ & $\begin{array}{l}\text { Positive (penile } \\
\text { ulcer swab) }\end{array}$ & $\begin{array}{l}\text { Positive: CGAb titre } \\
\text { 1:320 (STH); } \\
\text { CGAb/LGV CFT titre } \\
\text { 1:512 (HPA); CT } \\
\text { WIF (L2 strain) titre } \\
\text { 1:3000 (HPA, } \\
\text { Bristol) }\end{array}$ & $\begin{array}{l}\text { Doxycycline } \\
100 \text { mg twice } \\
\text { daily for } 3 \\
\text { weeks }\end{array}$ \\
\hline $\begin{array}{l}6 \text { April } 2007 \\
\text { STH }\end{array}$ & White British 34 & $\begin{array}{l}\text { Bilateral tender } 2 \mathrm{~cm} \\
\text { by } 3 \mathrm{~cm} \text { ruptured } \\
\text { buboes }\end{array}$ & Nil & $\begin{array}{l}\text { Positive CD4 } \\
787 \mathrm{VL}<40\end{array}$ & 1 & $\begin{array}{l}\text { Rectal and } \\
\text { pharyngeal GC } \\
\text { culture } \\
\text { Urethral swab } \\
\text { GC/CT (SDA) } \\
\text { Rectal swab GC/ } \\
\text { CT (SDA) } \\
\text { Bubo pus } \\
\text { bacterial and } \\
\text { mycobacterial } \\
\text { cultures } \\
\text { Syphilis EIA }\end{array}$ & $\begin{array}{l}\text { Positive (swab of } \\
\text { bubo pus) }\end{array}$ & Not done & $\begin{array}{l}\text { Doxycycline } \\
100 \text { mg twice } \\
\text { daily for } 3 \\
\text { weeks }\end{array}$ \\
\hline $\begin{array}{l}7 \text { July } 2007 \\
\text { MMC }\end{array}$ & White other 36 & $\begin{array}{l}\text { Tender right } 12 \mathrm{~cm} \\
\text { by } 6 \mathrm{~cm} \text { and left } \\
4 \mathrm{~cm} \text { by } 2 \mathrm{~cm} \\
\text { inguinal } \\
\text { lymphadenopathy }\end{array}$ & Nil & Negative & 4 & $\begin{array}{l}\text { Rectal swab CT } \\
\text { (PCR) } \\
\text { Urethral, rectal } \\
\text { and pharyngeal } \\
\text { GC culture } \\
\text { Syphilis EIA } \\
\text { Bubo aspirate } \\
\text { Urethral smear } \\
<4 \text { PMNLs/hpf }\end{array}$ & $\begin{array}{l}\text { Positive (urethral } \\
\text { swab PCR and } \\
\text { chlamydial } \\
\text { culture) }\end{array}$ & $\begin{array}{l}\text { Positive CGAb } \\
(1: 400)\end{array}$ & $\begin{array}{l}\text { Doxycycline } \\
100 \text { mg twice } \\
\text { daily for } 3 \\
\text { weeks }\end{array}$ \\
\hline
\end{tabular}


Table 1 Continued

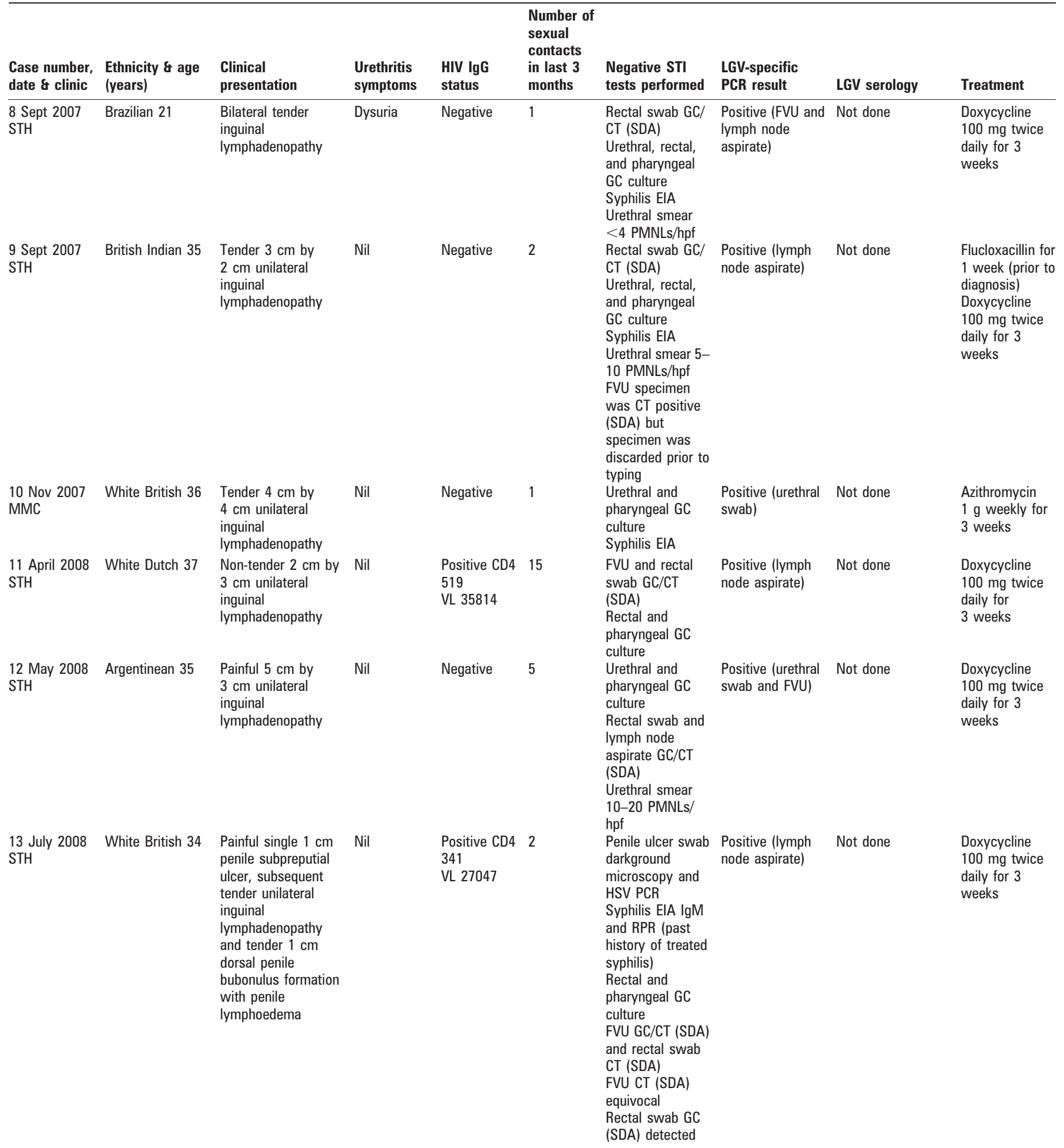

CFT, complement fixation test; CGAb, chlamydia group antibody; CT, Chlamydia trachomatis; C\&W, Chelsea and Westminster; EIA, enzyme immunoassay; FVU, first void urine; GC, Neisseria gonorrhoeae; HPA, Health Protection Agency; HSV, herpes simplex virus; MMC, Mortimer Market Centre; PCR, polymerase chain reaction; PMNLs/hpf, polymorphonuclear leucocytes per high power field (x100); RPR, rapid plasma reagin; STH, St Thomas' Hospital; SDA, strand displacement amplification; TPPA, Treponema pallidum particle agglutination; VDRL, Venereal Disease Research Laboratory; VL, viral load; WIF, whole immunofluorescence.

infection as their primary LGV lesion and none of the five reported any preceding anogenital ulceration, although such symptoms might have been transient and unnoticed. Six of the men reported only solitary sexual contacts in the previous 3 months, three of whom were their HIV positive regular male partners.

\section{Notable features of cases}

Of note, case 1 was first seen in December 2003 when he developed a tender right inguinal swelling. He reported regular unprotected insertive and receptive anal sex with anonymous male partners in London in the preceding months. On examination there was a single fluctuant $4 \mathrm{~cm}$ by $5 \mathrm{~cm}$ right 
inguinal swelling. Fine needle aspiration biopsy showed reactive lymphoid hyperplasia; Gram stain, microscopy and culture of the aspirate were negative for bacterial pathogens including mycobacteria. Oral amoxicillin $500 \mathrm{mg}$ three times daily and flucloxacillin $500 \mathrm{mg}$ four times daily were prescribed with no improvement in the mass, which ruptured spontaneously and discharged pus periodically for several months. The patient then began to pass red blood per rectum, developing tenesmus and showing weight loss. Colonoscopy in October 2004 showed an "unusual, chronic-looking fissure" in the anal canal and a purulent proctitis, biopsies of which showed acute and chronic inflammation with crypt abscesses and focal granuloma formation, consistent with LGV. A rectal swab specimen (ProbeTec, Becton Dickinson, Sparks, Maryland, USA) tested positive for $C$ trachomatis by strand displacement amplification (SDA). The inguinal and rectal symptoms resolved completely after 3 weeks of doxycycline treatment. LGV-specific DNA was detected retrospectively from rectal biopsy material using techniques described previously. ${ }^{8}$

Case 2 also had a complicated clinical course after first presenting in September 2005 with a week's history of a $5 \mathrm{~mm}$ tender ulcer over the right hemiscrotum and a healing perianal ulcer. He was prescribed a course of aciclovir and flucloxacillin but a swab from the ulcer tested negative for both herpes simplex virus (HSV) and $C$ trachomatis (ulcer swab and urethra). The patient re-presented 2 weeks later with worsening of the ulcer that was now indurated with granulation tissue evident in the base (see fig 1). This time an ulcer swab specimen tested positive for $C$ trachomatis by SDA subsequently confirmed to be LGV. Five days after testing the patient was recalled and by this time had developed an enlarged firm right inguinal node and was thus commenced on doxycycline $100 \mathrm{mg}$ twice daily for presumed LGV. After 10 days he had developed further lymphadenopathy above the inguinal ligament despite compliance with treatment. After 17 days of doxycycline, the swelling had progressed to a hot, fluctuant, $4 \mathrm{~cm}$ by $3 \mathrm{~cm}$ bubo confirmed with ultrasound. Treatment was switched to azithromycin $1 \mathrm{~g}$ daily but despite the change in antibiotic treatment the bubo continued to enlarge. Surgeons were reluctant to incise the lesion due to extensive overlying cellulitis but the abscess ruptured spontaneously 2 weeks after starting azithromycin. A sample of fluid draining from the sinus also tested positive for $C$ trachomatis and was later confirmed to be LGV. Symptoms improved on azithromycin, reduced to $500 \mathrm{mg}$ daily for the last 5 days. The lesions showed complete resolution after a total of 5 weeks treatment (18 days azithromycin and 17 days doxycycline) though some residual skin induration remained.

Case 4 had a 2-month history of a solitary, weeping, painless, indurated $0.7 \mathrm{~cm}$ ulcer in the dorsal coronal sulcus yet never developed inguinal lymphadenopathy.

Case 6 presented with bilateral $2 \mathrm{~cm}$ by $3 \mathrm{~cm}$ fluctuant lymph node abscesses that had ruptured spontaneously. The aspirated pus tested positive for $C$ trachomatis by SDA and confirmed to be LGV

Case 7 presented with striking clinical signs of a left-sided $12 \mathrm{~cm}$ by $6 \mathrm{~cm}$ inguinal mass and a smaller $4 \mathrm{~cm}$ by $2 \mathrm{~cm}$ mass on the right. An ultrasound study arranged by his general practitioner had shown multiple enlarged pathological-appearing lymph nodes bilaterally. A urethral swab specimen tested positive for $C$ trachomatis by chlamydial cell culture and Roche Cobas Amplicor PCR (Roche Diagnostics Systems, Branchburg, New Jersey, USA) and extracts from both were confirmed to be

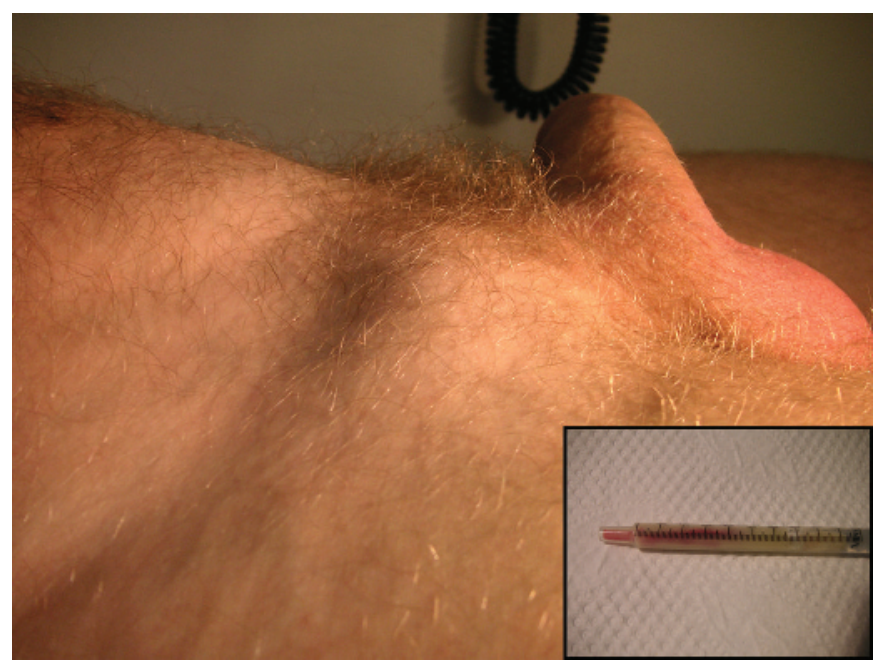

Figure 1 Clinical images from case 2 showing a small tender indurated scrotal ulcer (inset) and early right-sided inguinal lymphadenopathy that progressed to $3 \mathrm{~cm}$ by $4 \mathrm{~cm}$ bubo formation prior to spontaneous rupture. Lymphogranuloma venereum DNA was isolated from both ulcer swab and bubo pus.

LGV. The lesions resolved completely without rupture after a 3 week course of doxycycline.

Case 8 was admitted to hospital for investigation of bilateral inguinal lymphadenopathy with a differential diagnosis including lymphoma. His urine had tested positive for $C$ trachomatis by SDA 4 days before and he was reviewed in the GUM clinic where a diagnostic aspirate was performed from the nonfluctuant lymph node mass using $0.5 \mathrm{ml}$ normal saline (see fig 2) and the blood-stained material obtained was deposited onto a ProbeTec female swab. C trachomatis was detected using SDA and was confirmed to be LGV as was the DNA extract from his initial chlamydia-positive urine specimen. His symptoms and lesions resolved after 3 weeks of doxycycline treatment.

Case 9 also had a diagnostic aspirate performed from nonfluctuant inguinal lymphadenopathy and was started on doxycycline treatment. He returned the following day after the mass had doubled in size to $8 \mathrm{~cm}$ by $4 \mathrm{~cm}$ but it was still non-fluctuant. Urgent ultrasound assessment showed a cluster of enlarged lymph nodes up to $3 \mathrm{~cm}$ each in size with

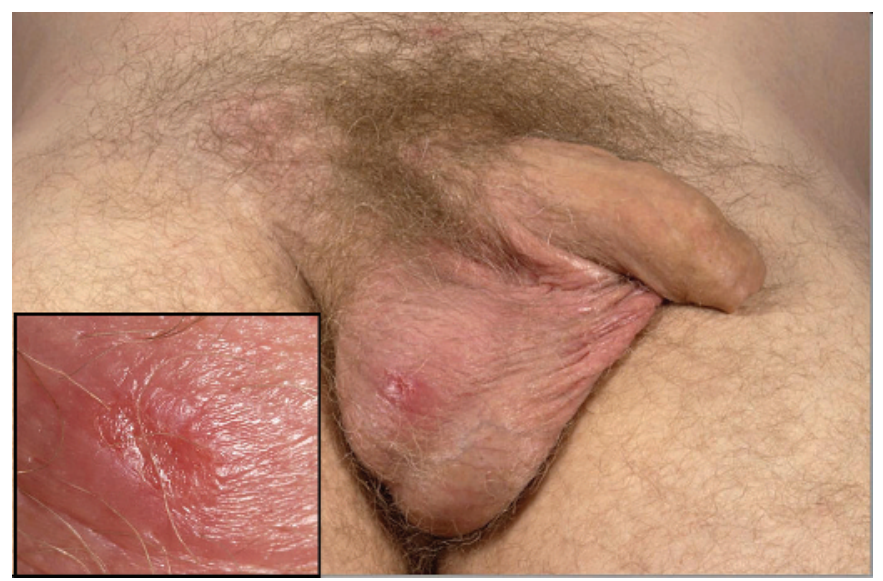

Figure 2 Clinical images from case 8 showing massive right inguinal lymphadenopathy that was tender but non-fluctuant. Inset shows aspiration of the mass with $0.5 \mathrm{ml}$ normal saline using a lateral approach, which obtained some blood-stained fluid that tested positive for lymphogranuloma venereum DNA. 
surrounding cellulitis and oedema but only a small $1.4 \mathrm{~cm}$ by $0.5 \mathrm{~cm}$ abscess situated deeply and not amenable to drainage. Doxycycline treatment was continued for 3 weeks and the symptoms and mass resolved without further suppuration.

Case 11 presented with a non-tender, non-fluctuant, lymph node swelling, yet $1 \mathrm{ml}$ of frank pus was aspirated from the node and this tested positive for $C$ trachomatis and confirmed to be LGV (fig 3).

Case 12 presented with a $3 \mathrm{~cm}$ by $5 \mathrm{~cm}$ right inguinal lymph node mass and asymptomatic LGV urethritis yet the nonpurulent lymph node aspirate tested negative for $C$ trachomatis by SDA.

Case 13 presented with a penile ulcer and subsequently developed unilateral inguinal lymphadenopathy as well as a penile bubonulus - only the second case to be described in the recent MSM LGV epidemic." His new male partner was asymptomatic but had LGV detected from a rectal swab specimen.

\section{DISCUSSION}

The cases described in this series differ epidemiologically from the typical MSM LGV proctitis cases seen thus far in the UK epidemic. Less than half was HIV positive compared with $74 \%$ of proctitis cases ${ }^{2}$ and other concurrent STIs were not detected. Half of the cases appear to have contracted LGV from relatively isolated episodes of sexual risk with far fewer recent sexual contacts than reported from most proctitis cases, particularly those seen early in the epidemic. ${ }^{2}$ Notably, most of the present cases reported no downstream sexual contacts following the onset of their symptoms and thus were unlikely to have transmitted LGV to subsequent partners. The prompt symptomatology and management seen in cases 2-13 suggests that they are unlikely to have been a source of onward transmission of LGV. In case 13, the index case's asymptomatic partner was

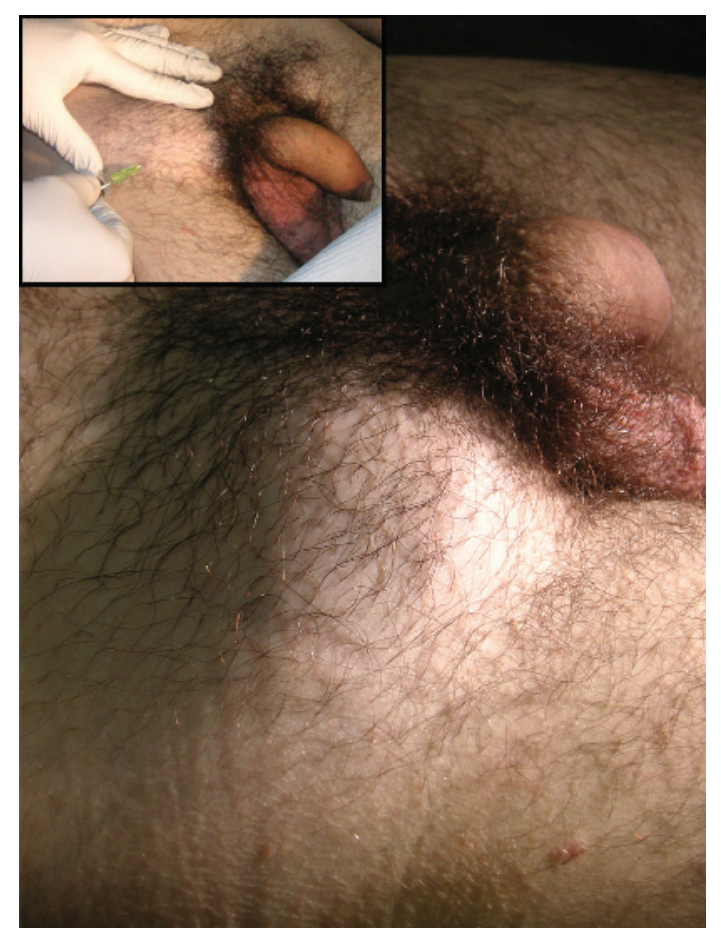

Figure 3 Clinical images from case 11 demonstrating right-sided nontender, non-fluctuant lymphadenopathy. Despite this, $1 \mathrm{ml}$ of frank pus (see inset) was aspirated from the node and this tested positive for lymphogranuloma venereum DNA. diagnosed subsequently with rectal LGV, reminding us that asymptomatic LGV exists in the MSM population. This is in accordance with findings from the Netherlands where $40 \%$ of men with LGV proctitis reported few complaints and/or had no physical abnormality. ${ }^{10}$ Nevertheless, a recent UK case finding exercise failed to demonstrate a significant reservoir of asymptomatic infection to explain persistent transmission ${ }^{11}$ and further work is needed to define true differences in LGV epidemiology between Dutch and British MSM.

While patient 1 was not diagnosed with LGV inguinal syndrome contemporaneously, his inclusion in the present series serves to demonstrate the consequences of missed diagnosis. He presented in an era when LGV was not recognised as a prevalent pathogen in the UK MSM population and much morbidity and onward transmission could have been averted by early diagnosis and treatment. It is not possible to determine if his eventual LGV proctitis was due to progression of his inguinal syndrome or from newly acquired anorectal infection.

Diagnosis of LGV is dependent on the detection of a LGVassociated serovar of $C$ trachomatis from the site of pathology; however, serology may be helpful should this fail and the clinical suspicion is high. Only three of five cases in our series showed typical serological responses and more work is needed to assess the diagnostic value of serology in this population.

The LGV genital ulcers seen in this series showed non-specific clinical features and clinicians should consider obtaining suitable specimens for C trachomatis/LGV when assessing anogenital ulceration in MSM. Swabs from ulcers and diagnostic aspirates of scant material from non-fluctuant inguinal lesions produced suitable specimens for the successful detection and typing of $C$ trachomatis using standard nucleic acid amplification assays and we recommend this approach for investigation of suspicious lesions.

Urethral $C$ trachomatis appears to have been the primary LGV lesion in five of the present cases. Variability in symptomatology and urethral smear microscopy findings in the present cases suggest that this might not simply represent LGV-associated urethritis and that other primary endourethral lesions such as ulceration may occur. We do not believe that routine LGV typing of $C$ trachomatis-positive urethral isolates from MSM is currently indicated, based on the rarity of urethral LGV seen in the UK case-finding exercise (Ward $\mathrm{H}$, in press). Nevertheless, in the presence of additional clinical signs such as ulceration or lymphadenopathy, or in LGV contacts, then referral of $C$ trachomatis-positive specimens for detection of LGV serovars is warranted.

The presence of persistent anogenital ulceration and severe proctitis can enhance HIV ${ }^{12}$ and possibly hepatitis C transmission. ${ }^{13}$ Although no new diagnoses were made within the present case series, incident HIV and hepatitis $C$ infection may not have been detected by testing performed at the time of LGV diagnosis and follow-up serology beyond the relevant window periods is indicated.

Treatment with doxycycline for 3 weeks achieved resolution of symptoms and signs in 11 of 12 patients and azithromycin in 2 patients using multiple-dose regimens. As demonstrated in patient 2, diagnosis of LGV can be challenging and patients with large buboes may require longer courses of treatment than the recommended 3 weeks. ${ }^{14}$ Adjuvant drainage of fluctuant abscesses may hasten the resolution of such lesions and prevent spontaneous rupture and sinus formation. There were no signs of tertiary sequelae such as chronic lymphoedema reported in any of the present cases although some local scarring was seen. 


\section{Key messages}

- Genital ulcers and inguinal node disease caused by lymphogranuloma venereum (LGV) have been observed in the current LGV epidemic in London in men who have sex with men (MSM).

- Chlamydia trachomatis nucleic acid tests performed on swabs, urine and lymph node aspirates provide suitable diagnostic specimens that allow confirmation by LGV-specific molecular analysis.

- LGV should be included in the differential diagnosis of anogenital ulceration in all MSM.

The present cases demonstrate that clinical manifestations of LGV have not been confined to proctitis in the current outbreak in MSM in the UK despite the predominance of anorectal disease reported. Clinicians who see MSM patients should familiarise themselves with the clinical features and diagnostic pathways illustrated in this series. The striking clinical signs seen in some of these cases, especially in those who were systemically unwell, led to provisional diagnoses of incarcerated herniae and lymphoma. In addition, there has been a recent report of two heterosexual LGV cases: ${ }^{15}$ further evidence that suggests the epidemic is spreading beyond its initial core group. Other relevant clinicians, including surgeons, microbiologists and histopathologists, should be alerted to the current epidemiology of LGV in the UK, Europe and the USA, and it should be considered in the differential diagnoses of proctitis, anogenital ulceration and inguinal lymphadenopathy, particularly in MSM.

Acknowledgements: The authors would like to thank the laboratory staff at St Thomas' Hospital, Mortimer Market Centre, and Chelsea and Westminster for their assistance in analysing specimens; Health Protection Agency Bristol for performing the chlamydial serology in case 4; and Professor Cathy Ison for helpful comments on the manuscript.

Competing interests: None.
Patient consent: Obtained.

Contributors: GS and JW conceived the paper, collected data on cases seen at St Thomas' Hospital, co-ordinated the multicentre collaboration and wrote the final draft; EA-J, JR, NTA and DH each contributed cases from their respective clinics and edited the manuscript; AE wrote the early first draft; SA was responsible for the molecular typing and verification of LGV results as well as editing the manuscript.

\section{REFERENCES}

1. Mabey D, Peeling RW. Lymphogranuloma venereum. Sex Transm Infect 2002;78:90-2.

2. Jebbari $\mathbf{H}$, Alexander $\mathrm{S}$, Ward $\mathrm{H}$, et al. Update on lymphogranuloma venereum in the United Kingdom. Sex Transm Infect 2007;83:324-6.

3. Nieuwenhuis RF, Ossewaarde JM, Gotz HM, et al. Resurgence of lymphogranuloma venereum in Western Europe: an outbreak of Chlamydia trachomatis serovar L2 proctitis in Netherlands among men who have sex with men. Clin Infect Dis 2004;39:996-1003.

4. Tinmouth J, Rachlis A, Wesson T, et al. Lymphogranuloma venereum in North America: case reports and an update for gastroenterologists. Clin Gastroenterol Hepatol 2006;4:469-73

5. Nieuwenhuis RF, Ossewaarde JM, van der Meijden WI, et al. Unusual presentation of early lymphogranuloma venereum in an HIV-1 infected patient: effective treatment with $1 \mathrm{~g}$ azithromycin. Sex Transm Infect 2003;79:453-5.

6. Chen CY, Chi KH, Alexander S, et al. The molecular diagnosis of lymphogranuloma venereum: evaluation of a real-time multiplex polymerase chain reaction test using rectal and urethral specimens. Sex Transm Dis 2007;34:451-5.

7. Morre SA, Spaargaren J, Fennema JS, et al. Real-time polymerase chain reaction to diagnose lymphogranuloma venereum. Emerg Infect Dis 2005;11:1311-2.

8. Martin IMC, Alexander SA, Ison CA, et al. Diagnosis of lymphogranuloma venereum from biopsy samples. Gut Oct 2006;55:1522-3.

9. Spenatto N, Boulinguez S, de Barbeyrac B, et al. First case of "bubonulus" in L2 lymphogranuloma venereum. Sex Transm Inf 2007;83:337-8

10. de Vries HJ, van der Bij AK, Fennema JS, et al. Lymphogranuloma venereum proctitis in men who have sex with men is associated with anal enema use and highrisk behaviour. Sex Transm Dis 2008;35:203-8.

11. Ward H, Alexander S, Carder C, et al. The prevalence of lymphogranuloma venereum infection in men who have sex with men: results of a multicentre case finding study. Sex Transm Infect 2009;85:173-5.

12. Galvin SR, Cohen MS. The role of sexually transmitted diseases in HIV transmission. Nat Rev Microbiol 2004;2:33-42.

13. Gotz HM, van Doornum G, Niesters HG, et al. A cluster of acute hepatitis C virus infection among men who have sex with men - results from contact tracing and public health implications. AIDS 2005:19:969-74.

14. BASHH Clinical Effectiveness Group National Guideline for the Management of Lymphogranuloma Venereum 2006. http://www.bashh.org/guidelines/2007/ lgv gdl revised final2 1106.pdf (accessed 24 February 2008).

15. de Munain JL, Ezpeleta G, Imaz M, et al. Two lymphogranuloma venereum cases in a heterosexual couple in Bilbao (Spain). Sex Transm Dis 2008;35:918-19. 
practice it would seem logical to prescribe PDE5i in order to produce good erections that MSM can be confident will be sustained even while putting on a condom. ${ }^{3}$ Unfortunately, the current data do not support this contention, rather showing an association between PDE5i usage and HIV prevalence. ${ }^{3}$ Recent quantitative and qualitative studies strongly suggest that the likelihood of MSM having unsafe sex and having HIV is significantly higher in those with current depression, fatigue, past and current sexual assault and regular users of recreational drugs to counteract the psychological sequelae of these psychosocial issues. ${ }^{4-6}$ Many of the recreational drugs used such as crystal meth and cocaine are profound peripheral vasoconstrictors as well as cerebral stimulants. ${ }^{3}$ Hence the need for PDE5i to counteract the erectile dysfunction produced by them. Furthermore, there is suggestive evidence that the use of PDE5i itself can reverse low mood, ${ }^{7}$ cause aggression and amnesia ${ }^{8}$ and enhance sensation for the receptive partner at anal sex. ${ }^{9}$ Enhanced engorgement of penile and anal areas with PDE5i may themselves predispose to HIV transmission. ${ }^{3}$ Other factors associated with erectile dysfunction in MSM with HIV are the use of antiretroviral drugs, particularly protease inhibitors ${ }^{10}$ and accelerated penile arterial pathology. ${ }^{11}$

Most of the studies showing an association between unsafe sex, HIV and PDE5i use in MSM indicate that these men do not acquire PDE5i from medical practitioners, but rather via the internet or other local contacts. ${ }^{3}$ With this in mind it would seem prudent for all MSM who attend for STI or HIV screening or therapy to be asked about erectile dysfunction at partnered sex, as well as other relevant clinical issues, as delineated above. Management should include the whole spectrum of the clinical disorders these men present with, including the prescribing of PDE5i medication, along with advice about appropriate condom and lubrication use and the minimalisation of recreational drug use and management of other psychosocial issues. Asking about these issues in busy STI/HIV clinics may not be easy, not least because of lack of time but also because of health practitioner and patient embarrassment in bringing up these issues. Some of the health issues related to PDE5i use, such as depression, are crucial to recognise, because they are associated with poor antiretroviral compliance. ${ }^{12}$
In spite of these complex interactions between PDE5i and other conditions, MSM are ethically entitled to receive these medications when there is clinical necessity. ${ }^{13}$

D Goldmeier', D Richardson ${ }^{2},{ }^{1}$ Imperial College NHS Trust at St Mary's Hospital, London, UK; ${ }^{2}$ Lawson Unit Royal Sussex County Hospital, Brighton, UK

Correspondence to: Dr David Goldmeier, Imperial College NHS Trust at St Mary's Hospital, London W2 1NY, UK; david.goldmeier@imperial.nhs.uk

Competing interests: DG has received educational grants from Pfizer, Bayer and Lilly. DR has no competing interests to declare.

Accepted 23 April 2009

Sex Transm Infect 2009;85:405-406. doi:10.1136/sti.2009.036780

\section{REFERENCES}

1. Crosby RA, Yarber W, Sanders S, Graham C. Is phosphodiesterase type 5 inhibitor use associated with condom breakage? Sex Transm Infect 2009;85:404-5.

2. Greenstein A, Chen J, Salonia A, et al. Does sildenafil enhance the quality of nocturnal erections in healthy young men? J Sex Med 2004;1:314-17.

3. Rosen RC, Catania JA, Ehrhardt AA, et al. The Bolger conference on PDE-5 inhibition and HIV risk: implications for health policy and prevention. J Sex Med 2006;3:960-75

4. Jerome JC, Halkitis PN. Siconolfi DE. Gender, sexual behavior and club drug use. Club drug use, sexual behavior and HIV seroconversion: a qualitative study of motivations. Substance Use Misuse 2009;44:431-47.

5. Stall R, Mills TC, Wiliamson J, et al. Association of co-occurring psychosocial health problems and increased vulnerability to HIV/AIDS among urban men who have sex with men. Am J Public Health 2003;93:939-42.

6. Lesserman J, Barroso J, Pence BW, et al. Trauma, stressful life events and depression predict HIV related fatigue. AIDS Care 2008;20:1268-5.

7. Orr G, Seidman SN, Weiser M, et al. An open label pilot study to evaluate the efficacy of sildenafil citrate in middle aged men with late onset dysthymia. J Nerv Mental Dis 2008;196:496-500.

8. Milman HA, Arnold SB. Neurological, psychological and aggressive disturbances with sildenafil. Ann Pharmacother 2002;36:1973-4.

9. Romanelli F, Kelly MS. Recreational use of sildenafil by HIV positive and negative homosexual/bisexual males. Ann Pharmacother 2004;38:1024-30.

10. Collazos J. Sexual dysfunction in the highly active antiretroviral therapy era. AIDS Rev 2007:9:237-45.

11. Boccara F. Cardiovascular complications and atherosclerotic manifestations in the HIV infected population: type, incidence and associated risk factors. AIDS 2008;22(Suppl 3):S19-26.

12. Pence BW. The impact of mental health and traumatic life experiences on the antiretroviral treatment outcomes for people living with HIV/AIDS. J Antimicrob Chemother 2009;63:636-40.

13. Sadeghi-Nejad H, Watson R, Irwin R, et al. Erectile dysfunction in the HIV positive male: a review of the medical legal and ethical considerations in the age of oral pharmacotherapy. Int J Imp Res 2000;12(Suppl 3):S49-53.

\section{Correction}

There was an error in an article published in the June issue of the journal (Sethi G, Allason-Jones E, Richens J, et al. Lymphogranuloma venereum presenting as genital ulceration and inguinal syndrome in men who have sex with men in London, UK. Sex Transm Infect 2009;85:165-70). Fig 1 was inserted above the legend for fig 2; fig 2 above the legend of fig 3 and fig 3 should have been placed with the legend from fig 1 . The correct figs and legends are available online at http://sti.bmj. com/cgi/content/full/85/3/165/DC1. The journal apologies for this error.

Sex Transm Infect 2009;85:406. doi:10.1136/sti.2008.034348.corr1 